\section{Vitamin D deficiency and its relationship with bone mineral density among postmenopausal women living in the tropics}

\author{
Deficiência de vitamina $D$ e sua relação com a densidade mineral \\ óssea em mulheres na pós-menopausa residentes nos trópicos
}

Francisco Bandeira', Luiz Griz', Eduardo Freese²,

Daniela Castro Lima' ', Ana Carolina Thé', Erik Trovão Diniz'1,

Thyciara Fontenele Marques', Cynthia Salgado Lucena'

\begin{abstract}
Objective: To determine vitamin D (25OHD) status and its relationship with bone mineral density (BMD) in 93 postmenopausal women. Subjects and methods: Patients were distributed in two groups: Group $1-51$ to 65 years $(n=45)$ and Group $2-66$ to 84 years $(n=48) ; 250 H D$ and PTH serum were analyzed and a DXA scan of the lumbar spine (LS) and femoral neck (FN) were taken. Results: Mean \pm SD of serum $250 \mathrm{HD}$ levels were $80.6 \pm 43.3 \mathrm{nmol} / \mathrm{L}$ (Group 1) and $63.7 \pm 27.6 \mathrm{nmol} / \mathrm{L}$ (Group 2); $24 \%$ had $25 \mathrm{OHD}$ levels $<25 \mathrm{nmol} / \mathrm{L}$ and $43.7 \%<50 \mathrm{nmol} / \mathrm{L}$. The prevalence of vitamin $D$ deficiency at the $62.5 \mathrm{nmol} / \mathrm{L}$ cutoff increased significantly with age. Patients with hypovitaminosis D had a lower BMD at the FN $(0.738 \pm 0.102$ vs. $0.793 \pm 0.115 \mathrm{~g} /$ $\mathrm{cm}, \mathrm{p}=0.03$ ) and had been postmenopausal for longer ( $21.0 \pm 8.4 \mathrm{vs} .16 .2 \pm 8.4$ years, $\mathrm{p}=0.01)$. Conclusion: We found a high prevalence of hypovitaminosis $D$ in postmenopausal women. Age, years elapsed since menopause and low BMD in the FN were associated with deficiency. Arq Bras Endocrinol Metab. 2010;54(2):227-32
\end{abstract}

Keywords

Vitamin D; osteoporosis; bone mineral density; PTH; hyperparathyroidism

\section{RESUMO}

Objetivo: Determinar o perfil da vitamina D (250HD) e sua relação com a densidade mineral óssea (DMO) em 93 mulheres na pós-menopausa. Sujeitos e métodos: As pacientes foram distribuídas em dois grupos: grupo 1 - 51 a 65 anos (45 pacientes) e 2 - 66 a 84 anos (48 pacientes); foram analisados $250 \mathrm{HD}$ e PTH séricos e realizou-se exame de DXA em coluna lombar (LS) e colo do fêmur (FN). Resultados: As médias \pm desvio-padrão (DP) dos níveis de 25OHD foram $80,6 \pm 43,3 \mathrm{nmol} / \mathrm{L}$ (grupo 1) e $63,7 \pm 27,6 \mathrm{nmol} / \mathrm{L}$ (grupo 2); $24 \%$ tinham $250 \mathrm{HD}<25 \mathrm{nmol} / \mathrm{L}$ e $43,7 \%,<50 \mathrm{nmol} / \mathrm{L}$. A prevalência de deficiência de $250 \mathrm{HD}$, considerando $62,5 \mathrm{nmol} / \mathrm{L}$ como ponto de corte, aumentou significativamente com a idade. Pacientes com hipovitaminose D tinham uma menor DMO no FN $\left(0,738 \pm 0,102\right.$ vs. 0,793 $\left.\pm 0,115 \mathrm{~g} / \mathrm{cm}^{2}, \mathrm{p}=0,03\right)$ e maior tempo de pós-menopausa $(21,0 \pm 8,4$ vs. $16,2 \pm 8,4$ anos, $p=0,01)$. Conclusão: Encontrou-se alta prevalência de hipovitaminose $\mathrm{D}$ em mulheres na pós-menopausa. Idade, anos desde a menopausa e baixa DMO no FN estavam associados à deficiência. Arq Bras Endocrinol Metab. 2010;54(2):227-32

Descritores

Vitamina D; osteoporose; densidade mineral óssea; PTH; hiperparatiroidismo
1 Divisão de Endocrinologia, Hospital Agamenon Magalhães, Sistema Único de Saúde (SUS), Ministério da Saúde, Universidade de Pernambuco (UPE), Centro de Osteoporose de Pernambuco, Recife, PE, Brasil

${ }^{2}$ Centro de Pesquisa Médica, Fundação Oswaldo Cruz (Fiocruz), Ministério da Saúde, Recife, PE, Brasil

Correspondence to: Francisco Bandeira Divisão de Endocrinologia, Hospital Agamenon Magalhães, UPE Estrada do Arraial, 2723 52021-380 - Recife, PE, Brasil fbandeira@gmail.com

Received on Feb/4/2009 Accepted on Oct/8/2009 


\section{INTRODUCTION}

$\mathrm{I}$ n countries close to the Equator the ultraviolet radiation of the sun penetrates the ozone layer of the Earth's stratosphere sufficiently to permit the production of vitamin $\mathrm{D}$ by the skin throughout the year. It should be emphasized, however, that the very process of aging leads to a diminution in the skin's ability to produce vitamin $\mathrm{D}$ because of the diminution in the amount of 7-dehydrocholesterol. A 70-year-old individual exposed to the same amount of ultraviolet sunrays manages to produce only $20 \%$ of the amount produced by a young person (1).

Although severe vitamin D deficiency leading to rickets or osteomalacia is rare in Brazil, there is accumulating evidence of the frequent occurrence of subclinical vitamin D deficiency in several other countries, especially in the elderly. As a result, we find secondary hyperparathyroidism, increased bone remodeling, a decrease in bone mineral density (BMD), particularly in the proximal femur, and an increased risk of osteoporotic fractures, when compared with individuals considered to have a sufficient supply of vitamin D (2).

Some initial data suggested that at least $50 \mathrm{nmol} / \mathrm{L}$ would be needed to satisfactorily meet metabolic requirements, especially in elderly persons, since below this there would be a rise in serum parathyroid hormone (PTH) and increased bone remodeling (3). When these individuals were given a vitamin $\mathrm{D}$ supplement raising the serum 25-hydroxyvitamin D (25OHD) to values above $5 \mathrm{nmol} / \mathrm{L}$, PTH levels fell by approximately $40 \%$, and bone mass increased.

There is clearly no consensus regarding ideal serum levels of $25 \mathrm{OHD}$, and there are data in the literature indicating 50,62.5, 75, and even $92.5 \mathrm{nmol} / \mathrm{L}$ as the minimum level required (4-7). Levels below 37.5 $\mathrm{nmol} / \mathrm{L}$ are regarded as representing a significant deficiency. In patients visiting an osteoporosis clinic, PTH levels clearly increase when the serum levels of $25 \mathrm{OHD}$ fall below $62.5 \mathrm{nmol} / \mathrm{L}$ and there is a significant increase in bone remodeling and loss of bone mass with levels even lower than $75 \mathrm{nmol} / \mathrm{L}(8)$.

In Brazil, a mainly tropical country, a proper amount of vitamin D in the population is to be expected. In two studies conducted in elderly patients living in the southeast of Brazil (latitude $20-30^{\circ} \mathrm{S}$ ), a high prevalence of vitamin $\mathrm{D}$ deficiency was demonstrated (9-12). Thus the aim of this study was to evaluate the prevalence of vitamin D deficiency and its relationship with BMD in postmenopausal women visiting an endocrine outpatient clinic in Recife, which is situated at 10 degrees of latitude south of the Equator.

\section{SUBJECTS AND METHODS}

This was a cross-sectional study, which involved ninetythree postmenopausal women evaluated on an outpatient basis at Agamenon Magalhães Hospital, Recife. The following inclusion criterion was applied: postmenopausal women visting our endocrine outpatient clinic for routine medical evaluation. The exclusion criteria adopted were as follows: patients on drugs, such as glucocorticoids and anticonvulsants, known to lead to bone loss; patients on hormone replacement therapy; and those with diseases that affect bone metabolism, contributing to osteoporosis, such as multiple myeloma, diseases of the kidney or liver, malabsorption diseases, Paget's disease, primary hyperparathyroidism and uncontrolled hypo- or hyperthyroidism.

Menopause was defined as the absence of menstruation for at least 2 years in women over 45 years. For determining the diagnosis and extent of osteoporosis WHO criteria were used.

Patients were divided into two groups according to age: Group $1-51$ to 65 years $(\mathrm{n}=45)$ and Group 2 66 to 84 years $(\mathrm{n}=48)$.

The study protocol was approved by the Ethics Committee of Agamenon Magalhães Hospital, University of Pernambuco.

\section{Vitamin D and PTH measurements}

25-hydroxyvitamin $\mathrm{D}$ was measured in the serum by radioimmunoassay (DiaSorin Inc., Stillwater, USA). The sensitivity of the assay, defined as the lowest value different from zero, was $3.75 \mathrm{nmol} / \mathrm{L}$ and the interassay coefficient of variation was $5 \%$. In our laboratory the reference values for healthy premenopausal women range from 25.7 to $148 \mathrm{nmol} / \mathrm{L}$, with a median of $57 \mathrm{nmol} / \mathrm{L}$. PTH was measured by automated electrochemoluminescence (Elecsys - Roche Diagnostics GmbH, Mannheim, Germany), with a detection limit of $1.2 \mathrm{pg} / \mathrm{mL}$.

\section{Determination of bone mineral density}

BMD was measured by the Dual Energy X-ray Absorptiometry (Lunar Corporation, Madison, WI, USA) at the LS from L2 to L4 anteroposteriorly and the proximal femur, including the FN, Ward's triangle and tro- 
chanter. The results are expressed in $\mathrm{g} / \mathrm{cm}^{2}$, T-score. We used a local database (reference population aged 20 to 29 years) to calculate the T-score. The mean $( \pm S D)$ of normal values for women was $1.085 \mathrm{~g} / \mathrm{cm}^{2}( \pm 0.1)$ at the lumbar spine, $0.913 \mathrm{~g} / \mathrm{cm}^{2}( \pm 0.12)$ at the femoral neck and $0.316 \mathrm{~g} / \mathrm{cm}^{2}( \pm 0.07)$ at the distal radius and for men it was $1.188 \mathrm{~g} / \mathrm{cm}^{2}( \pm 0.12), 0.966 \mathrm{~g} / \mathrm{cm}^{2}$ $( \pm 0.13)$ and $0.332 \mathrm{~g} / \mathrm{cm}^{2}( \pm 0.08)$ at the lumbar spine, femoral neck and distal radius, respectively. The in vivo precision error of the equipment employed in the study expressed in percentage coefficient of variation $(\% \mathrm{CV}=$ $\mathrm{SD}+$ mean BMD of repeated measurements) was $0.9 \%$ for the lumbar spine on the anteroposterior view and $1.2 \%$ for the femoral neck.

\section{Statistical analysis}

The prevalences of vitamin D deficiency in different age groups were compared using the Mantel-Haenszel chi-square test. Comparison of BMD values in patients with and without vitamin $\mathrm{D}$ deficiency was made by analysis of variance (ANOVA) and the Wilcoxon test for two samples. $\mathrm{P}$ values $<0.05$ were considered statistically significant. The Pearson correlations between age and 25OHD and between PTH and 25OHD were also obtained.

\section{RESULTS}

The mean \pm SD age was $65.6 \pm 7.07$ years. Mean serum $25 \mathrm{OHD}$ was $71.9 \pm 36.9 \mathrm{nmol} / \mathrm{L}$ (Table 1 ); for groups 1 and 2 , these values were, respectively, $80.6 \pm 43.3$ $\mathrm{nmol} / \mathrm{L}$ and $63.7 \pm 27.6 \mathrm{nmol} / \mathrm{L}$.

Table 1. Mean values of studied variables for 93 postmenopausal women

\begin{tabular}{lccc}
\hline & Mean \pm SD & Median & $\begin{array}{c}\text { Coefficient } \\
\text { of variation } \\
\text { (\%) }\end{array}$ \\
\hline Age (yr) & $65.61 \pm 7.07$ & 66.0 & 10.77 \\
BMl $\left(\mathrm{Kg} / \mathrm{m}^{2}\right)$ & $26.64 \pm 3.5$ & 26.63 & 13.14 \\
Years since menopause $(\mathrm{yr})$ & $17.52 \pm 7.38$ & 17.0 & 42.11 \\
\hline LS BMD (g/cm²) & $0.96 \pm 0.16$ & 0.96 & 16.62 \\
FN BMD (g/cm²) & $0.78 \pm 0.11$ & 0.76 & 14.19 \\
\hline 25-OHD (ng/ml) & $28.84 \pm 14.79$ & 25.20 & 51.30 \\
PTH (pg/ml) & $47.18 \pm 15.84$ & 44.0 & 33.58 \\
\hline
\end{tabular}

$\mathrm{SD}=$ standard deviation; $\mathrm{BMI}=$ body mass index; $\mathrm{LS} B M D=$ bone mineral density at lumbar spine; FN BMD = bone mineral density at femoral neck.

Twenty-four percent $(95 \% \mathrm{CI}=45.2-66.4)$ of the patients had levels below $50 \mathrm{nmol} / \mathrm{L}, 19.7 \%(95 \% \mathrm{CI}$ $=12.2-29.4$ ) between 50 and $62.5 \mathrm{nmol} / \mathrm{L}$, and $56 \%$
$(95 \% \mathrm{CI}=45.2-66.4)$ above $62.5 \mathrm{nmol} / \mathrm{L}$. Eight per cent had significant vitamin D deficiency (serum 25 OHD levels lower than $37.5 \mathrm{nmol} / \mathrm{L}$ ).

With regard to age group, the prevalence of vitamin D deficiency was $30 \%$ in patients from 50 to 59 years old, $32.5 \%$ in patients from 60 to 69 years old, $54.5 \%$ in patients from 70 to 79 years old, and $83 \%$ in patients over the age of 80 (Figure 1).

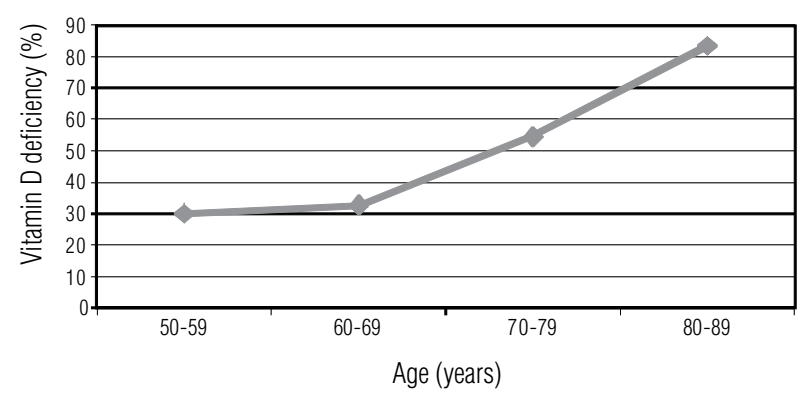

Figure 1. Prevalence of vitamin $D$ deficiency / insufficiency by age group.

In Group 1 patients with serum 25OHD levels below $50 \mathrm{nmol} / \mathrm{L}$ we observed lower values for bone mineral density at the femoral neck (FNBMD) than in those whose $25 \mathrm{OHD}$ levels were above $50 \mathrm{nmol} / \mathrm{L}$ $\left(0.70 \pm 0.14 \mathrm{~g} / \mathrm{cm}^{2}\right.$ vs. $\left.0.81 \pm 0.10 \mathrm{~g} / \mathrm{cm}^{2} ; \mathrm{p}=0.01\right)$. The difference remained significant when cutoffs of $62.5 \mathrm{nmol} / \mathrm{L}\left(0.73 \pm 0.12 \mathrm{~g} / \mathrm{cm}^{2}\right.$ vs. $0.81 \pm 0.11 \mathrm{~g} /$ $\left.\mathrm{cm}^{2} ; \mathrm{p}=0.01\right)$ and $75 \mathrm{nmol} / \mathrm{L}\left(0.75 \pm 0.10 \mathrm{~g} / \mathrm{cm}^{2} v s\right.$. $\left.0.84 \pm 0.13 \mathrm{~g} / \mathrm{cm}^{2} ; \mathrm{p}=0.007\right)$ were used. Regarding bone mineral density at the lumbar spine (LSBMD), using a cutoff of $75 \mathrm{nmol} / \mathrm{L}$, we also observed significant differences in the younger group 1 patients $(0.92 \pm$ $0.14 \mathrm{~g} / \mathrm{cm}^{2}$ vs $1.01 \pm 0.15 \mathrm{~g} / \mathrm{cm}^{2} ; \mathrm{p}=0.04$ ) (Table 2 ) .

A significant negative correlation was detected between 25OHD and age $(\mathrm{r}=-0.2310 ; \mathrm{p}<0.05)$ and between PTH and 25OHD ( $\mathrm{r}=-0.2899 ; \mathrm{p}<0.05)$.

Regarding the $62.5 \mathrm{nmol} / \mathrm{L}$ cutoff for determining whether a patient has vitamin $\mathrm{D}$ deficiency or insufficiency, we found statistically significant differences in comparison with the patients with vitamin D levels greater than $62.5 \mathrm{nmol} / \mathrm{L}$. Patients with vitamin $\mathrm{D}$ deficiency were older $(68.7 \pm 8.8$ vs $64.7 \pm 7.1$ years, $\mathrm{p}=$ $0.02)$, had been postmenopausal for longer $(21.0 \pm 8.4$ vs $16.2 \pm 8.4$ years, $\mathrm{p}=0.01)$, and had a lower bone density at the femoral neck $(0.738 \pm 0.102$ vs $0.793 \pm$ $0.115 \mathrm{~g} / \mathrm{cm}, \mathrm{p}=0.03$ ) (Table 3 ). Mean serum PTH was $52.9 \pm 14.5 \mathrm{pg} / \mathrm{mL}$ in patients with $25 \mathrm{OHD}$ levels lower than $62.5 \mathrm{nmol} / \mathrm{L}$ and $39.7 \pm 7.8 \mathrm{pg} / \mathrm{mL}$ in patients with levels equal to or greater than $62.5 \mathrm{nmol} / \mathrm{L}$, $\mathrm{p}=0.002$ (Figure 2). 
Table 2. Differences in BMI, years since menopause, LSBMD, FNBMD and PTH among postmenopausal women according to age and various serum $250 \mathrm{HD}$ cut points

\begin{tabular}{|c|c|c|c|c|c|c|c|c|c|c|}
\hline & & \multicolumn{2}{|c|}{ 250HD (nmol/L) } & \multirow{2}{*}{ p } & \multicolumn{2}{|c|}{ 250HD (nmol/L) } & \multirow{2}{*}{ p } & \multicolumn{2}{|c|}{ 250HD (nmol/L) } & \multirow{2}{*}{ p } \\
\hline & & $<50$ & $\geq \mathbf{5 0}$ & & $<62.5(43)$ & $\geq 62.5$ & & $<75$ & $\geq 75$ & \\
\hline \multirow{2}{*}{$\mathrm{BMI}$} & Group 1 & $24.29 \pm 3.20$ & $26.11 \pm 2.62$ & 0.0713 & $24.44 \pm 2.88$ & $26.34 \pm 2.62$ & $0.0318^{\star}$ & $24.65 \pm 2.81$ & $27.45 \pm 1.87$ & $0.0007^{\star}$ \\
\hline & Group 2 & $26.23 \pm 3.36$ & $28.29 \pm 3.98$ & 0.0719 & $26.97 \pm 3.76$ & $28.29 \pm 3.95$ & 0.2478 & $24.60 \pm 3.87$ & $27.22 \pm 3.99$ & 0.7764 \\
\hline \multirow{2}{*}{ YSM } & Group 1 & $16.00 \pm 5.8$ & $12.09 \pm 5.21$ & 0.0655 & $14.53 \pm 6.70$ & $12.17 \pm 5.08$ & 0.2313 & $13.32 \pm 5.97$ & $12.35 \pm 5.36$ & 0.7270 \\
\hline & Group 2 & $22.72 \pm 5.78$ & $21.23 \pm 6.34$ & 0.4963 & $22.46 \pm 6.13$ & $20.25 \pm 6.14$ & 0.4766 & $22.38 \pm 6.43$ & $19.82 \pm 4.64$ & 0.2957 \\
\hline \multirow{2}{*}{ LSBMD } & Group1 & $0.91 \pm 0.18$ & $0.97 \pm 0.14$ & 0.3068 & $0.93 \pm 0.16$ & $0.97 \pm 0.14$ & 0.3270 & $0.92 \pm 0.14$ & $1.01 \pm 0.15$ & $0.0419^{\star}$ \\
\hline & Group 2 & $0.98 \pm 0.19$ & $0.96 \pm 0.17$ & 0.7474 & $0.99 \pm 0.17$ & $0.94 \pm 0.18$ & 0.4131 & $0.98 \pm 0.18$ & $0.92 \pm 0.16$ & 0.3255 \\
\hline \multirow{2}{*}{ FNBMD } & Group 1 & $0.70 \pm 0.14$ & $0.81 \pm 0.10$ & $0.0113^{\star}$ & $0.73 \pm 0.12$ & $0.81 \pm 0.11$ & $0.0186^{\star}$ & $0.75 \pm 0.10$ & $0.84 \pm 0.13$ & $0.0070^{\star}$ \\
\hline & Group 2 & $0.74 \pm 0.07$ & $0.78 \pm 0.11$ & 0.1226 & $0.76 \pm 0.08$ & $0.78 \pm 0.12$ & 0.3658 & $0.77 \pm 0.09$ & $0.78 \pm 0.12$ & 0.7035 \\
\hline \multirow{2}{*}{ PTH } & Group 1 & $48.49 \pm 15.53$ & $39.09 \pm 13.47$ & 0.0664 & $51.29 \pm 15.51$ & $36.12 \pm 10.76$ & $0.0004^{\star}$ & $44.06 \pm 14.56$ & $36.43 \pm 12.96$ & 0.0832 \\
\hline & Group 2 & $53.18 \pm 13.39$ & $52.59 \pm 16.48$ & 0.8982 & $53.06 \pm 14.28$ & $52.46 \pm 16.88$ & 0.8938 & $54.36 \pm 16.26$ & $47.60 \pm 10.12$ & 0.2001 \\
\hline
\end{tabular}

Group 1 = women 51-65 years; Group 2 = women 66-84 years; 250HD = 25-hidroxi-vitamin D; BMI = body mass index; YSM = years since menopause; LSBMD = lumbar spine bone mineral density; FNBMD = femoral neck bone mineral density; PTH = parathyroid hormone.

${ }^{\star} p<0.05$.

Table 3. Characteristics of the study patients according to serum levels of 25 -hydroxivitamin $\mathrm{D}$ at the cut point of $62.5 \mathrm{nmol} / \mathrm{L}$

\begin{tabular}{lccc}
\hline $\begin{array}{l}\text { Characteristics } \\
\text { (mean } \mathbf{\text { SD}} \text { ) }\end{array}$ & $\begin{array}{c}\mathbf{2 5 0 H D} \\
\mathbf{6 2 . 5} \mathbf{~ n m o l} / \mathbf{L}\end{array}$ & $\begin{array}{c}\mathbf{2 5 0 H D} \\
\geq \mathbf{6 2 . 5} \mathbf{~ n m o l} / \mathbf{L}\end{array}$ & $\mathbf{p}$ \\
\hline Age (years) & $68.7 \pm 8.8$ & $64.7 \pm 7.1$ & $\mathbf{0 . 0 2}$ \\
BMI $\left(\mathrm{kg} / \mathrm{m}^{2}\right)$ & $26.7 \pm 4.3$ & $26.3 \pm 4.8$ & 0.6 \\
Years since menopause & $21.0 \pm 8.4$ & $16.2 \pm 8.4$ & $\mathbf{0 . 0 1}$ \\
LSBMD $\left(\mathrm{g} / \mathrm{cm}^{2}\right)$ & $0.945 \pm 0.183$ & $0.957 \pm 0.149$ & 0.8 \\
FNBMD $\left(\mathrm{g} / \mathrm{cm}^{2}\right)$ & $0.738 \pm 0.102$ & $0.793 \pm 0.115$ & $\mathbf{0 . 0 3}$ \\
PTH $(\mathrm{pg} / \mathrm{ml})$ & $52.95 \pm 14.5$ & $39.7 \pm 10.8$ & $\mathbf{0 . 0 0 2}$ \\
\hline
\end{tabular}

$\mathrm{SD}=$ standard deviation; $\mathrm{BMI}=$ body mass index; $\mathrm{LSBMD}=$ bone mineral density at lumbar spine; FNBMD = bone mineral density at femoral neck, PTH = parathyroid hormone.

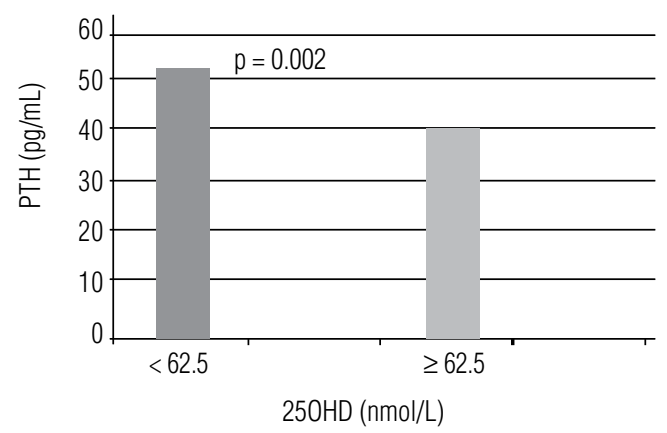

Figure 2. Serum PTH according to 25-hydroxy-vitamin D (250HD) levels.

\section{DISCUSSION}

This was the first study of vitamin D deficiency in postmenopausal women conducted in northeast Brazil. The other Brazilian studies were carried out in places more distant from the Equator, namely São Paulo, Minas Gerais and Rio Grande do Sul.
In a study of 250 elderly individuals from São Paulo $\left(23^{\circ} \mathrm{S}\right)$ with a mean age of 79 years, mean serum $25 \mathrm{OHD}$ was $19.8 \mathrm{ng} / \mathrm{mL}$, and overall $57 \%$ of them showed values below $50 \mathrm{nmol} / \mathrm{L}$ (9). A study conducted in the same city with 177 inpatients (mean age 76.6 years) and 243 outpatients (mean age 79.1 years) showed a prevalence of hypovitaminosis D (250HD $<50 \mathrm{nmol} / \mathrm{L}$ ) of $71.2 \%$ and $43.8 \%$, respectively (10). This prevalence is higher than that found in our study even when considering only the outpatients. Meanwhile, two other studies $(13,14)$ also conducted in São Paulo with young and elderly patients found mean $25 \mathrm{OHD}$ levels of $78.5 \mathrm{nmol} / \mathrm{L}$ and $77.4 \mathrm{nmol} / \mathrm{L}$, respectively, only slightly above the mean found in this study $(71.98 \pm 36.91 \mathrm{nmol} / \mathrm{L})$.

In Rio Grande do Sul (latitude $30^{\circ} \mathrm{S}$ ) Premaor and cols. (11) evaluating 81 elderly inpatients found a prevalence of hypovitaminosis $\mathrm{D}(25 \mathrm{OHD}<50 \mathrm{nmol} / \mathrm{L})$ of $77.8 \%$ (11), while Scalco and cols. (12) studying 102 institutionalized elderly with mean age of 77.8 years demonstrated a vitamin D deficiency in $85.7 \%$ of them (12).

In Minas Gerais (latitude $19^{\circ} \mathrm{S}$ ) a study conducted by Silva and cols. (15) showed a vitamin D deficiency $(25 \mathrm{OHD}<80 \mathrm{nmol} / \mathrm{L})$ in $42.4 \%$ of 180 patients with a mean age of 58.8 years, predominantly women (15).

Vitamin D has also been evaluated in other Latin American countries. In Buenos Aires (latitude $34^{\circ} \mathrm{S}$ ), Argentina, 27\% of women between 40 and 90 years old had serum vitamin $\mathrm{D}<50 \mathrm{nmol} / \mathrm{L}$ in summer, which is similar to what was found in southeast Brazil in winter. 
On the other hand, the prevalence increased to $71 \%$ in the winter months (16). Furthermore, only 2 of 40 postmenopausal women evaluated in Chile had hypovitaminosis D. However, a 25OHD level $<37 \mathrm{nmol} / \mathrm{L}$ was considered (17).

Our data showed a prevalence similar to that seen in the USA, but greater than that of Canada and the Scandinavian countries (4), reinforcing the idea that the abundant presence of sunlight may not prevent vitamin $\mathrm{D}$ deficiency in postmenopausal women. Moreover, the Brazilian diet is very deficient in vitamin $\mathrm{D}$, the main source of which is fatty fish. In Canada and the Scandinavian countries $25 \mathrm{OHD}$ levels are significantly higher than those of the patients in the present study. In those countries, despite the lower amount of sunlight there is a broader range of natural food sources and there is also fortification of milk with vitamin D.

It is also important to bear in mind that in countries with an arid or semi-arid climate, with a very low amount of rainfall and therefore sunny weather throughout the year, vitamin D deficiency attains one of the highest prevalence rates on the whole planet $(18,19)$. Moreover, the populations of such countries have specific dietary habits and wear clothing that may explain these results. Even though the city of Recife has a humid tropical climate (latitude $10^{\circ} \mathrm{S}$ ), these data from arid and semi-arid regions also serve to strengthen the notion that, at least in postmenopausal women, the abundance of sunlight may not prevent vitamin D deficiency.

Although we have not performed any sun exposure evaluations, a recent study from Honolulu, Hawaii (latitude $21^{\circ} \mathrm{N}$ ) demonstrated a high prevalence of vitamin $\mathrm{D}$ deficiency despite abundant sun exposure in a population of 93 adults over 18 years of age (20).

Our data also demonstrated that the mean of serum $25 \mathrm{OHD}$ levels was similar to that found in our postmenopausal patients who had primary asymptomatic hyperparathyroidism (21) and was also no different from the levels reported in the North American patients in the MORE study (4).

As vitamin $\mathrm{D}$ deficiency may be asymptomatic, albeit predisposing to a greater loss of bone and consequent increased risk of fractures, it is important that each region should attempt to establish the lowest limit of normality for serum $25 \mathrm{OHD}$, defined as the level at which mean serum PTH levels begin to rise, characterizing secondary hyperparathyroidism (22). We found significant differences in the serum PTH levels up to the $62.5 \mathrm{nmol} / \mathrm{L}$ cutoff for serum 25OHD.
A Brazilian study, using the cutoff of $50 \mathrm{nmol} / \mathrm{L}$, found a prevalence of secondary hyperparathyroidism of $54 \%$ in outpatients, showing a negative correlation between 25OHD and PTH (10). In another Brazilian study, in which a $25 \mathrm{OHD}$ cutoff of $80 \mathrm{nmol} / \mathrm{L}$ was used, the increase in PTH was significant and an inverse correlation between both measurements was also observed (15).

The report by Binkley and cols. (23) highlighted the importance of validation of circulating $25 \mathrm{OHD}$ assays in the user's laboratory regardless of the manufacturer's claims, as we did for our assay. They compared the results of serum 25OHD measurement from samples of postmenopausal women referred to different laboratories. The DiaSorin RIA which we use in our laboratory demonstrated excellent results when compared with the HPLC standard method and has been very effective in detecting endogenous 25OHD2 and 25OHD3 in human serum $(23,24)$.

In conclusion, we found a high prevalence of vitamin D deficiency among healthy postmenopausal women who were seen for routine medical evaluation irrespective of age group. Patients with 25OHD levels lower than $62.5 \mathrm{nmol} / \mathrm{L}$ were significantly older, longer past the menopause, and had a significantly much lower BMD at the femoral neck and higher PTH levels.

Disclosure: no potential conflict of interest relevant to this article was reported.

\section{REFERENCES}

1. Holick M, Matsuoka LY, Wortsman J. Age, vitamin D, and solar ultraviolet radiation. Lancet. 1989;4:1104-5.

2. Sahota O, MasudT, San P. Vitamin D insufficiency increases bone turnover at the hip in patients with established vertebral osteoporosis. Clin Endocrinol (Oxf). 1999;51:217-21.

3. Rosen CJ, Morrison A, Zhou H. Elderly women in northern New England exhibit seasonal changes in bone mineral density and calciotropic hormones. Bone Miner. 1994; 25:83-92.

4. Lips , Duong T, Oleksik A, Black DM, Cummings S, Cox D, et al. The Multiple Outcomes of Raloxifene Evaluation Study Group. A global study of vitamin D status and parathyroid function in postmenopausal women with osteoporosis: baseline data from the multiple outcomes of raloxifene evaluation clinical trial. J Clin Endocrionol Metab. 2001;86:1212-18.

5. Haden ST, Fuleihan GE, Agell JE, Cotran NM. Calcidiol and PTH levels in women attending an osteoporosis program. Calcif Tissue Int. 1999;64:275-79.

6. Chapuy MC, Preziosi P, Maaner P, Delmas P. Prevalence of vitamin $D$ insufficiency in an adult normal population. Osteoporos Int. 1997;7:439-43.

7. Thomas MK, Demay M.B. Vitamin D deficiency and disorders of vitamin D metabolism. Endocrinol Metab Clin North Am. 2000;29:1-17. 
8. Wagman RB, Marcus M. Beyond bone mineral density - navigating the laboratory assessment of patients with osteoporosis. J Clin Endocrinol Metab. 2002;87:4429-30.

9. Saraiva GL, Cendoroglo MS, Ramos LR, Araújo LM, Vieira JG, Kunii I, et al. Influence of ultraviolet radiation on the production of 25 hydroxyvitamin $D$ in the elderly population in the city of São Paulo (23 $34^{\prime}$ S) Brazil. Osteoporos Int. 2005;16:1649-54.

10. Saraiva GL, Cendoroglo MS, Ramos LR, Araújo LMQ, Vieira JGH, Maeda SS, et al. Prevalência da deficiência, insuficiência de vitamina $D$ e hiperparatiroidismo secundário em idosos institucionalizados e moradores na comunidade da cidade de São Paulo, Brasil. Arq Bras Endocrinol Metab. 2007;51(3):437-42.

11. Premaor MO, Alves GV, Crossetti LB, Furlanetto TW. Hyperparathyroidism secondary to hypovitaminosis $D$ in hypoalbuminemic is less intense than in normoalbuminemic patients: a prevalence study in medical inpatients in southern Brazil. Endocrine. 2004;24(1):47-53.

12. Scalco R, Premaor MO, Fröehlich PE, Furlanetto TW. High prevalence of hypovitaminosis $\mathrm{D}$ and secondary hyperparathyroidism in the elderly living in nonprofit homes in South Brazil. Endocrine. 2008;33(1):95-100.

13. Maeda SSK, Lazaretti-Castro M. Influência sazonal sobre as concentrações de 25-hidroxivitamina $\mathrm{D}$ em população idosa ativa na cidade de São Paulo. Arq Bras Endocrinol Metab. 2003;48:503.

14. Maeda SSK, Hayashi L, Pereira RL, Lazaretti-Castro M. Influência dos aspectos ocupacionais e da sazonalidade nas concentrações de 25-hidroxivitamina $\mathrm{D}$ em população jovem saudável da cidade de São Paulo. Arq Bras Endocrinol Metab. 2003;48:501.

15. Silva BC, Camargos BM, Fujii JB, Dias EP, Soares MM. Prevalência de deficiência e insuficiência de vitamina $D$ e sua correlação com PTH, marcadores de remodelação óssea e densidade mineral óssea, em pacientes ambulatoriais. Arq Bras Endocrinol Metabol. 2008;52(3):482-8.

16. Fradinger $E E$, Zanchetta JR. Vitamin $D$ status in women living in Buenos Aires. Medicina (B Aires). 1999;59:449-52.

17. Rodríguez Portales JA. Hipovitaminosis D en mujeres postmenopáusicas con masa ósea baja en la región metropolitana. Rev Med Chile. 2001;129:849-52.

18. Alagol F, Shihadeh $Y$, Boztepe $H$, Tanakol R. Sunlight exposure and vitamin $\mathrm{D}$ deficiency in Turkish women. J Endocrinol Invest. 2000;23:173-77.

19. Ganage-Yared MH, Chemali R, Yaacoub N, Asmar A. Hypovitaminosis $D$ in a sunny country: relation to lifestyle and bone markers. J Bone Miner Res. 2000;15:1856-62.

20. Binkley N, Novotny R, Krueger D, Kawahara T, Daida YG, Lensmeyer G, et al. Low Vitamin D Status despite Abundant Sun Exposure. J Clin Endocrinol Metab. 2007;92:2130-35.

21. Bandeira F, Caldas G, Freese E, Griz L, Faria M, Bandeira C. Relationship between serum vitamin $D$ status and clinical manifestations of primary hyperparathyroidism. Endocr Pract. 2002;8:266-70.

22. Thomas MK, Lloyd-Jones DM, Thadhani RI, Demay MB. Hypovitaminosis D in medical inpatients. N Engl J Med. 1998;338:777-83.

23. Binkley N, Krueger D, Cowgill CS, Plum L, Lake E, Hansen KE, et al. Assay variation confounds the diagnosis of hypovitaminosis D: a call for standardization. J Clin Endocrinol Metab. 2004;89:3152-57.

24. Hollis BW. The determination of circulating 25-hydroxyvitamin D: no easy task. J Clin Endocrinol Metab. 2004;89:3149-51. 